\title{
Immobilising Microalgae and Cyanobacteria as Biocomposites: New Opportunities to Intensify Algae Biotechnology and Bioprocessing
}

\author{
Gary S. Caldwell 1,*®D, Pichaya In-na ${ }^{2}$, , Rachel Hart ${ }^{1}$, Elliot Sharp ${ }^{3}$, Assia Stefanova ${ }^{4}$, Matthew Pickersgill ${ }^{2,5}$, \\ Matthew Walker ${ }^{1}$, Matthew Unthank ${ }^{3}{ }^{1}$, Justin Perry ${ }^{3}$ and Jonathan G. M. Lee ${ }^{2}$ \\ 1 School of Natural and Environmental Sciences, Newcastle University, Newcastle upon Tyne NE1 7RU, UK; \\ R.Hart1@newcastle.ac.uk (R.H.); M.J.Walker@newcastle.ac.uk (M.W.) \\ 2 School of Engineering, Newcastle University, Newcastle upon Tyne NE1 7RU, UK; \\ p.in-na@newcastle.ac.uk (P.I.-n.); m.pickersgill@newcastle.ac.uk (M.P.); \\ Jonathan.Lee@newcastle.ac.uk (J.G.M.L.) \\ 3 Department of Applied Sciences, Northumbria University, Newcastle upon Tyne NE1 8ST, UK; \\ Elliot.b.sharp@northumbria.ac.uk (E.S.); matthew.unthank@northumbria.ac.uk (M.U.); \\ justin.perry@northumbria.ac.uk (J.P.) \\ 4 School of Architecture, Planning \& Landscape, Newcastle University, Newcastle upon Tyne NE1 7RU, UK; \\ a.stefanova@newcastle.ac.uk \\ 5 Northumbrian Water Ltd., Bran Sands, Tees Dock Road, Middlesbrough TS6 6UE, UK \\ * Correspondence: gary.caldwell@newcastle.ac.uk; Tel.: +44-(0)1912086660
}

check for updates

Citation: Caldwell, G.S.; In-na, P.; Hart, R.; Sharp, E.; Stefanova, A.; Pickersgill, M.; Walker, M.; Unthank, M.; Perry, J.; Lee, J.G.M. Immobilising Microalgae and Cyanobacteria as Biocomposites: New Opportunities to Intensify Algae Biotechnology and Bioprocessing. Energies 2021, 14, 2566. https://doi.org/10.3390/en14092566

Academic Editor: Jaakko Puhakka

Received: 1 April 2021

Accepted: 28 April 2021

Published: 29 April 2021

Publisher's Note: MDPI stays neutral with regard to jurisdictional claims in published maps and institutional affiliations.

Copyright: (c) 2021 by the authors. Licensee MDPI, Basel, Switzerland. This article is an open access article distributed under the terms and conditions of the Creative Commons Attribution (CC BY) license (https:/ / creativecommons.org/licenses/by/ $4.0 /)$.

\begin{abstract}
There is a groundswell of interest in applying phototrophic microorganisms, specifically microalgae and cyanobacteria, for biotechnology and ecosystem service applications. However, there are inherent challenges associated with conventional routes to their deployment (using ponds, raceways and photobioreactors) which are synonymous with suspension cultivation techniques. Cultivation as biofilms partly ameliorates these issues; however, based on the principles of process intensification, by taking a step beyond biofilms and exploiting nature inspired artificial cell immobilisation, new opportunities become available, particularly for applications requiring extensive deployment periods (e.g., carbon capture and wastewater bioremediation). We explore the rationale for, and approaches to immobilised cultivation, in particular the application of latex-based polymer immobilisation as living biocomposites. We discuss how biocomposites can be optimised at the design stage based on mass transfer limitations. Finally, we predict that biocomposites will have a defining role in realising the deployment of metabolically engineered organisms for real world applications that may tip the balance of risk towards their environmental deployment.
\end{abstract}

Keywords: bioreactor; carbon capture; carbon dioxide; eutrophication; immobilization; latex polymers; process intensification; wastewater

\section{Introduction}

Two of the three dominant mass microalgae and cyanobacteria (hereon microalgae) cultivation systems (ponds and photobioreactors) focus on maintaining the cells as a colloidal suspension, equivalent to the microalgae living within the planktonic state, i.e., free floating within the water column with minimal physical cell-cell or cell-substratum interactions. The third main cultivation system (biofilm bioreactors) exploits surface attachment, equivalent to the cells living within the benthic or substratum-associated state, defined by more or less continuous cell-cell and cell-substratum interactions (Figure 1a,b).

There are pros and cons for each approach, particularly when attempting to culture at industrial scale. Ponds are advantageous in terms of their simplicity (both to build and operate) and their low capital costs, but they consume large tracts of land, are inefficient with water use [1] and, if used for remediation services (e.g., wastewater treatment), 
the cells, i.e., the active biomass, are subject to washout from the process (hydraulic retention time, i.e., how long cultures are retained within the pond, is a critical operational parameter [2]). Further, their dependence on ambient light and temperature, combined with their vulnerability to contamination from non-target organisms (predators, pathogens, competitors) makes achieving consistent performance challenging [3-7].

(a)

(c)

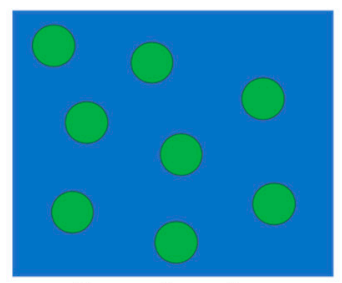

Suspension culture

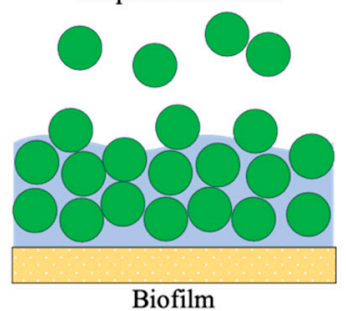

(e)

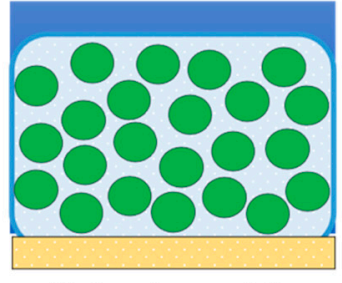

(g)
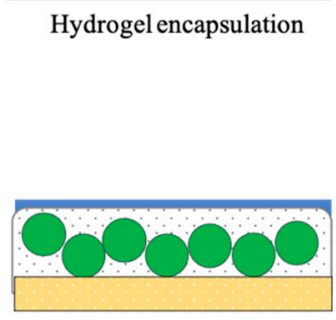

Latex immobilisation

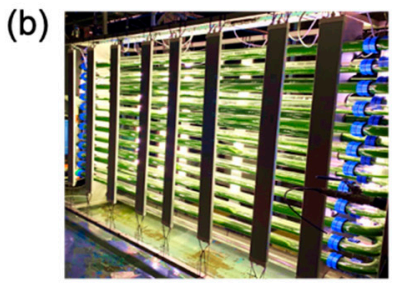

(d)

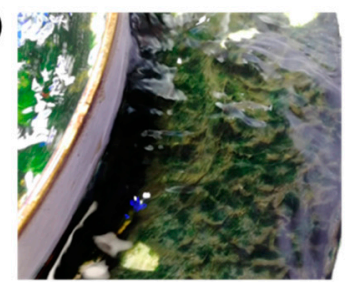

(f)

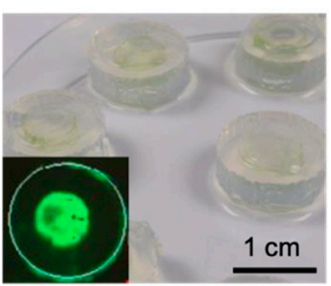

(h)

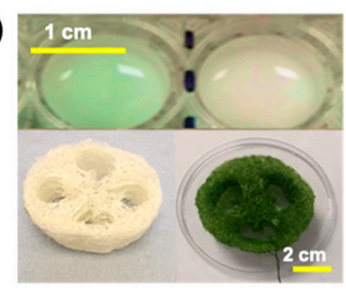

Figure 1. Comparing cell distribution and approaches for cell retention in mass microalgae cultivation: (a) Schematic of suspension culture-typical of ponds, raceways and photobioreactors. The cells are free floating in the growth medium, maintaining spatial separation through electrochemical repulsion which limits cell density; (b) artificially illuminated tubular photobioreactor using suspension cultivation for wastewater treatment; (c) open biofilm culture-cells attach to a substratum and biofilm cohesion is maintained through the natural production of extracellular polymeric substances (EPS). Biofilms are prone to failure leading to biomass loss; (d) cyanobacteria biofilm within a small raceway used for wastewater remediation; (e) encapsulated biofilms-cells are embedded within an artificial EPS, typically a hydrogel. Encapsulated biofilms are vulnerable to failure from desiccation of the hydrogel and subsequent loss of integrity; (f) microalgae encapsulated within kappa-carrageenan. Inset shows the chlorophyll fluorescence of the cells using imaging pulse amplitude modulated fluorometry; (g) latex biocomposites-cells are immobilised within materials other than hydrogels, such as latex; and (h) cyanobacteria in suspension as a biocoating in wet latex (upper left), the latex without cells is shown for comparison (upper right). The biocoating will be applied to a loofah sponge scaffold (lower left is uncoated, lower right is coated). Biocomposites have longer service lives that other immobilisation systems and, depending on the nature of the binder, can deliver orders of magnitude improvements in performance compared with the other cultivation systems. 
Photobioreactors ameliorate many of the drawbacks of open ponds (reduced land and water consumption, improved control of culture conditions, and substantially reduced threat from non-target organisms) culminating in greater biomass yield [8,9]; however, these gains come at the cost of higher capital and operating costs [10].

Both approaches share some drawbacks, such as challenges around maximising carbon dioxide $\left(\mathrm{CO}_{2}\right)$ mass transfer [11]. However, other shortcomings are more explicitly linked with the colloidal suspension, notably limitations in cell density and difficulty in harvesting. The planktonic state has evolved partly to minimise intraspecific resource competition, particularly for light and nutrients (including carbon). Microalgae typically have negative cell surface charges (measured as the zeta-potential) which drives cell-cell repulsive forces and establishes stable colloidal suspensions. This allows each cell to occupy its own space (c.f. sphere of influence) within the water column, together with the light and nutrients associated with that space. Further, by limiting physical cell-cell interactions, the microalgae (many of which have no means of independent motility) reduce the risk of floc formation (flocculation) which would otherwise increase the cell's sinking rate (Stoke's Law) from sunlit surface waters (photic zone), thereby compromising photosynthesis and threatening cell survival.

In stark contrast, algae that constitute biofilms have made a virtue out of a necessity. Rather than investing in means to maintain spatial separation, benthic microalgae proactively engage in intimate associations with the substratum, as well as actively encouraging close association with both con- and heterospecifics. This benthic niche negates the risk of sinking from the photic zone (the cell is attached to a stable surface), thus enabling the cells to focus on beneficial cell-cell interactions rather than treating these antagonistically. Nevertheless, the electrochemical repulsive forces must still be overcome. This is achieved through the production of copious extracellular polymeric substances (EPS) which function both as glue and medium through which the cells may move (many benthic microalgae are motile, particularly diatoms, often using EPS production and release to facilitate gliding movement).

Whereas the evolutionary benefit of overcoming the existential threat of sinking is recognised, it does come at a cost. Biofilm dwelling cells compromise on the guaranteed access to 'wrap around' space and resource beholden of their planktonic siblings. Whereas the living space along the xy-plane is only limited by the dimensions of the substratum, occupation of the z-plane is strictly limited by light penetration and EPS cohesiveness, particularly under shear stress. This commonly results in biofilm failure (Figure 1b), which may be accidental or deliberate (many biofilm organisms maintain the capacity to escape the biofilm as a means of dispersal).

Biofilm or attached microalgae cultivation, both as monospecific and mixed cultures, have been developed as alternatives to suspension culture [12,13], particularly for wastewater treatment applications. Biofilm formation can be initiated by adhering a concentrated algae cell paste to a solid supporting material such as glass fiber reinforced plastic [14], filter paper [15], cellulose ester membrane [16], polyester [17,18], polypropylene, [19], polyvinyl chloride, polyacrylonitrile [20], polytetrafluoroethylene [21], polycarbonate, cellulose acetate/nitrate, or polyethylene membranes [22], polyurethane [23,24], nylon or stainless steel mesh [25] and even concrete [26]. Natural fibres such as cotton, chamois cloth and loofah sponge (aka Luffa plant) have also been trialled [27-29] and have successfully outperformed suspension culture controls [30,31]. Subsequently, the cells produce EPS to assist surface attachment, forming a stable matrix [32].

Biofilm cultivation may be divided into three types: (1) permanently immersed in a liquid medium, (2) biofilms that alternate between gaseous and liquid phases, and (3) permeated biofilms wherein liquid medium is delivered through the substratum [33] (Figure 2). The productivity of two phase systems can greatly exceed that of raceways [34], although they generally require rotation or a rocking motion to expose the biofilm to both gaseous and liquid phases [35,36], although this may be difficult to scale up. Most studies 
with permeated biofilms have arranged their systems vertically to minimise the footprint and thereby the land requirement.

(a)

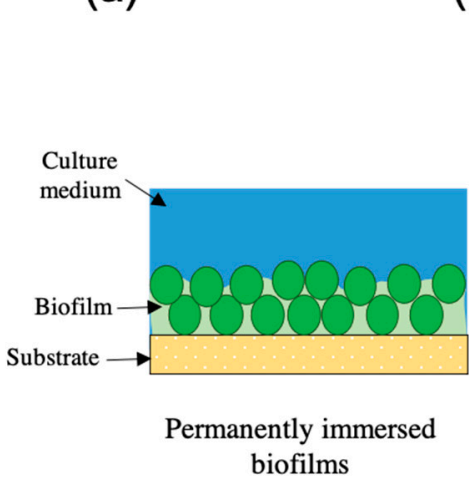

(b)

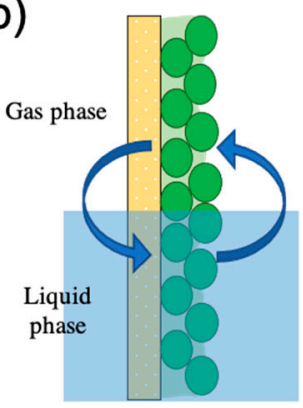

Biofilm between two phases (c)

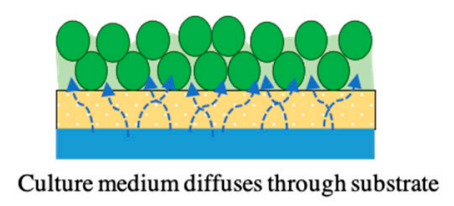

Permeated biofilms

Figure 2. Illustration of: (a) a permanently immersed biofilm in which the cells have continuous access to water and nutrients. A degree of mixing of the growth medium is required to prevent nutrient and $\mathrm{CO}_{2}$ exhaustion at the boundary between biofilm and water (solid-liquid interface); (b) a biofilm between two phases whereby rotational or oscillatory motion of the biofilm is used to ensure the biofilm is sequentially exposed to liquid and gas phases-this ameliorates the need to mix the growth medium but presents challenges around the impacts of shear stress on biofilm cohesion; and (c) a permeated biofilm in which capillary forces are utilised to wick growth medium through the solid support on which the biofilm is attached. This approach requires neither mixing or motion but is dependent on the selection of an appropriate porous and hydrophilic substratum [13].

Biofilms are intuitively attractive from a mass cultivation perspective as they consume less water (EPS is strongly hydrophilic, conferring good gelling properties and promoting the biofilm to remain hydrated), the cells have evolved to grow in high density situations (enabling the footprint of any culture operation to be reduced), light penetration is more easily controlled, $\mathrm{CO}_{2}$ mass transfer is improved, and biomass harvesting and dewatering are much easier. However, technical challenges remain; notably the prevalent contamination threat from non-target organisms, the potential for the biofilm to excessively desiccate, and of course the risk that the biofilm may fail as part of the natural biofilm lifecycle. There is the added complication that not all microalgae are amenable to (or even capable of) biofilm formation, i.e., the genetic ties to the planktonic existence are so deep rooted that other than through radical intervention (e.g., gene editing) such species must be deemed non-starters. Or must they?

There is a "Fourth Way" [37] to mass microalgae cultivation that involves the deliberate immobilisation of microalgae within 'engineered biofilms' or 'living biocomposites' [38-40] (Figure 1c,d). A number of studies have developed biocoatings (a binder containing live microbes) and biocomposites (a biocoating applied to a supporting structural material) with different microorganisms for a range of environmental applications including biofuel production, gas and chemical synthesis, environmental remediation, and as biosensors [41-44]. Many have successfully reported that biocoatings and biocomposites can intensify biological process and performance relative to suspension cultures [45-47]. In this article, we explore the rationale for, and approaches to immobilised cultivation, focusing on latexbased polymer immobilisation, and discuss how biocomposites can be optimised at the design stage based on mass transfer limitations.

\section{Immobilised Cultivation}

There are six immobilisation types: (1) affinity immobilisation, (2) adsorption, (3) covalent coupling, (4) confinement in a liquid-liquid emulsion, (5) capture behind a semipermeable membrane, and (6) entrapment within polymers [40] (Figure 3). These techniques can be separated into passive and active methods. Passive immobilisation utilises 
the natural attachment ability of microorganisms to natural or synthetic surfaces, while active immobilisation uses artificial techniques including flocculent agents, chemical attachment, and gel/polymer entrapment $[48,49]$. Affinity immobilisation is a very mild method and is based on complementary biomolecular interactions which do not involve drastic reactions and no chemical exposure. The method is often used for purification or separation of biomolecule mixtures and a desorption step is required to extract compounds from the immobilised substrate [50]. Adsorption immobilisation is a reversible process involving cells that strongly adhere to the sorbent. Covalent coupling is a well-known immobilisation technique for enzymes, but not for living cells because cell division can lead to cell leakage from loose bonding. Confinement in liquid-liquid emulsions is an aqueous method in which phase separation occurs from two different water-soluble polymers based on their surface properties [40]. For semi-permeable membranes, the cells are immobilised into the membrane and this technique is often used for biosensor fabrication. However, this method causes excessive accumulation of biomass growth on the substrate, which leads to pressure build up and damages the membrane [40]. Entrapment and encapsulation in polymers are the most common immobilisation methods, in which the cells are captured in a matrix made from synthetic polymers (e.g., acrylamide, polyurethanes, polyvinyl, polystyrene), proteins (e.g., gelatine, collagen, egg white) or natural polysaccharides (e.g., agars, carrageenan, alginates) [49]. These two techniques have been widely used to immobilise many microalgae species on various polymers for wastewater applications.

(a)

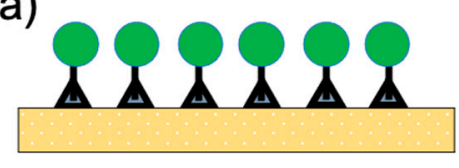

Affinity binding

(c)

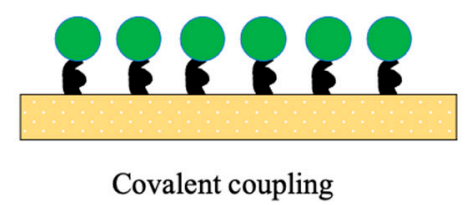

(e)

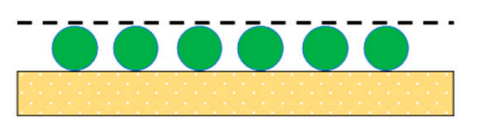

Capture behind semi-permeable membrane (b)

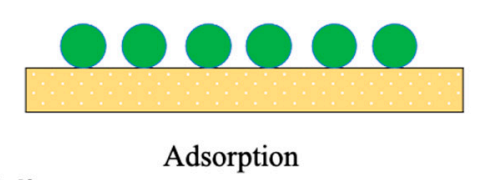

(d)

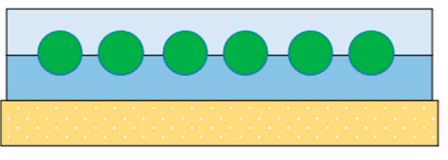

Confinement in liquid-liquid emulsion

(f)

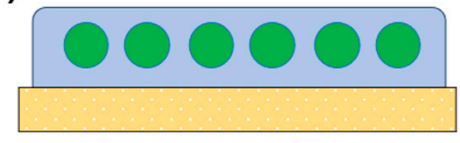

Polymer entrapment

Figure 3. Illustration of the six main approaches to immobilisation: (a) affinity binding, which is based on complementary biomolecular interactions; (b) adsorption, which is a process involving cells that strongly adhere to a sorbent; (c) covalent coupling, which is effective for enzymes but not for cells; (d) confinement in liquid-liquid emulsion, which exploits phase separation between two different water-soluble polymers based on their surface properties; (e) capture behind a semipermeable membrane, in which cells are immobilised into the membrane, however this method is prone to failure of the membrane in response to high pressure from excessive accumulation of biomass; and, (f) polymer entrapment, in which cells are embedded in a matrix comprising synthetic or natural polymers.

\section{Effects of Immobilisation on Microalgae}

Biocomposites include one or more discontinuous phases that provide solid support, and a continuous phase creating a matrix around the discontinuous [51]. Biocomposites comprising natural fibres (plant, animal, and mineral materials) are widely used due to their high tensile strength, low weight, and resistance to degradation [52,53]. Biocomposites retain biomass whilst allowing the exchange of molecules across a semi-permeable mem- 
brane [39]. It is important to note that biocomposites are different from biofilm reactors. The matrix in which cells are held should also act as protection from non-target organisms whilst still providing room for cellular maintenance and growth [54]. Biocomposites should support greater biomass within a smaller surface area, supported by improved cell retention [47]. This in turn confers greater flexibility in bioreactor design compared with suspension or biofilm counterparts.

Immobilising microalgae can improve photosynthetic rate, growth, and pigment and lipid content compared with suspension cultures $[49,55,56]$. Some studies have reported toxicity of some polymer immobilising techniques, with chemical forces and interactions between the matrix and the cell wall causing significant stresses on both the material and the entrapped microorganisms [39]. Mallick [40] summarised the fundamental elements for effective immobilisation and argues for ideal properties of the matrix. Immobilisation should retain cell viability and metabolic activity at high cell densities (through photosynthesis if using phototrophs), with low levels of cell loss from the matrix. To achieve this, the immobilising matrix should be non-toxic, appropriately transparent, chemically stable when exposed to growth media, and be mechanically robust.

Many immobilisation studies have focussed on entrapment within gel-like matrices such as alginate, carrageenans or chitosan [57-59]. There are several problems with gel immobilisation, notably cell leaching due to matrix breakdown over time. Furthermore, as gels are often up to $90 \%$ water, they are prone to rapid desiccation resulting in poor mechanical properties when rehydrated [60].

Alginates are permeable and transparent mannuronic and guluronic acid polymers from brown macroalgae which are cheap, nontoxic, and easy to process [61]. The microorganisms do not experience extreme physicochemical conditions during the immobilisation process [39]. Despite the benefits, the polymeric structure cannot be maintained when high phosphate concentrations or high cation levels (e.g., $\mathrm{K}^{+}$and $\mathrm{Mg}^{2+}$ ) are present [62]. Similarly, sodium alginate beads degrade when exposed for more than two weeks to wastewater with high phosphorous and nitrogen levels [63]. However, their mechanical resistance can be doubled if mixed with 5-10 kDa chitosan [64]. Carrageenans are polysaccharides extracted from red algae, and are known to support microalgae growth and metabolism $[65,66]$. Iota carrageenan forms clear elastic gels in the presence of calcium salts, and is thermo-reversible at $50-55{ }^{\circ} \mathrm{C}$ [67]. Lambda-carrageenan only forms high viscosity solutions [68] and cannot be used for microalgae biocoatings. Kappa-carrageenan can be mixed with potassium salts to produce strong and rigid set gels or with calcium salts to form brittle gels [68]; and although opaque, they can be made transparent with the addition of sugar [67]. Chitosan, a linear amino polysaccharide of $\beta$-D-glucosamine [39], is a promising microalgae immobilising agent [69-71]. It is insoluble in neutral and alkaline solutions which allows the gel structure to be formed at room temperature [72].

The use of gel-hardeners such as $\mathrm{CaCl}_{2}$ can compromise bioprocess efficiency and may result in cell loss [73]. Furthermore, increasing the thickness of a chitosan or alginate matrix to prevent cell leaching will only reduce the mass transfer of target nutrients such as $\mathrm{N}, \mathrm{P}$, and $\mathrm{CO}_{2}$ [74]. The use of cross-linkers in hydrogel systems can cause intracellular damage to microalgae; most likely due to the presence of glutaraldehyde [49].

\section{Latex Polymer Immobilisation}

Latexes are widely used in the printing and coatings industries to ensure strong adhesiveness, and greater flexibility and porosity of the products [74,75]. Latex coatings can be made with high precision and with controllable thickness using Mayer rod drawdown. The technique is limited to coating thicknesses of $>10 \mu \mathrm{m}$ although it can be used to produce multi-layered coatings [76]. Convective assembly is an alternative method enabling the creation of layer-by-layer coatings with rapid, well-ordered, and scalable fabrication [77].

Latex films form in three stages; (1) consolidation-the evaporation of water to form a packed latex particle network, (2) compaction-particle deformation begins to eliminate void space between latex particles, and (3) coalescence-polymer diffusion is initiated 
between particles in contact with one another to form the complete film (Figure 4) [78]. The first immobilisation of microorganisms (yeast and E. coli) using latex polymers was conducted in 1991 [79]. The mixture was coated onto an activated carbon particle mesh and calcium carbonate was mixed into the biocoating to generate porosity. Since then, several studies have immobilised many microorganisms (mostly bacteria) with latex polymers onto different solid supports $[47,74,80]$. Synechococcus PCC 6301 immobilised with different latex emulsions on a carbon electrode maintained nearly $100 \%$ of its photosynthetic activity upon rehydration [81]. Photosynthetic microorganisms have also been immobilised onto filter paper using acrylate copolymer latex polymers to produce artificial leaf biocomposites for hydrogen production with a service life of over $1000 \mathrm{~h}$. The specific photosynthetic rate was enhanced by up to 10 times compared to the suspension controls $[82,83]$.

(a)

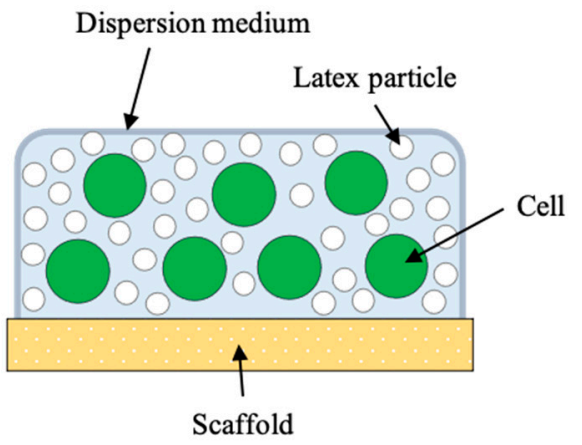

(c)

Latex particle deformation and packing around cells

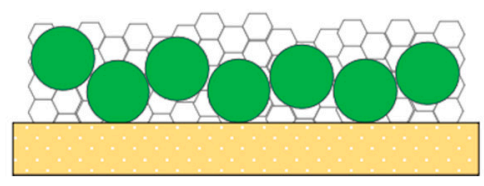

(b)

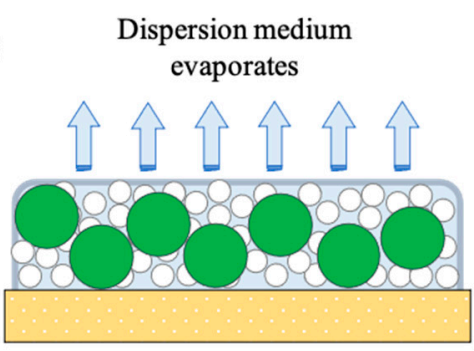

(d)

Interdiffusion of latex particles forming a thin film with entrapped cells

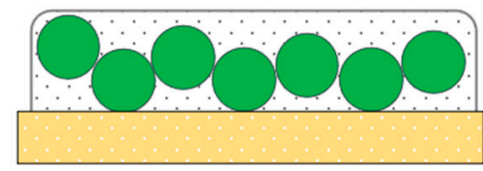

Figure 4. Illustration of the formation of latex films on a surface: (a) the latex-cell suspension is deposited onto the scaffold surface. At this stage the cells and latex particles have some scope for movement; (b) as the dispersion medium evaporates the cells and latex particles become confined to a thin layer and the immobilisation process has commenced; (c) following the evaporation of the dispersion medium the latex particles deform and pack around the cells, both attaching them to the scaffold and creating a protective film at the atmosphere boundary; and, (d) immobilisation is complete following the interdiffusion of the latex particles.

In addition to being low cost and with easy access to non-toxic waterborne latex emulsions [46,75], there are numerous biophysical advantages of using latex for cell immobilisation. High cell loadings can be used (500-1000 fold greater than for suspension culture), coinciding with good longevity of the microbes $(>1000 \mathrm{~h}$ after re-hydration $[76,84,85])$, particularly if osmoprotectants (e.g., glycerol) are added [47,74,77], and mass transfer rates can be improved due to the capacity to produce very thin coatings.

This is not to say that latex based immobilisation is without issues-film formation and therefore subsequent efficacy of the biocomposites can be affected due to the coating formulation, glass transition temperature $(\mathrm{Tg})$, particle size and distribution, particle morphology, drying and humidity, substrate choice, and biomass loading [80,86-89]. The drying temperature can have significant effects on latex coalescence on porous substrates, where rapid absorption of the aqueous phase into the substrate may result in cracking of the latex [90]. There is also concern regarding gas and liquid mass transfer to immobilised microbes which may limit cellular productivity. There is an inverse relationship between film thickness and mass transfer, therefore film thickness should be minimised whilst ensuring microbes remain immobilised yet metabolically active $[85,91]$. Therefore, a balance 
must be struck between latex thickness (which will impact cell retention) versus cells remaining metabolically active with mass transfer of $\mathrm{CO}_{2}$ and nutrients via the growth media not being limited.

There are methods to mitigate these, for example, latexes that do not require drying to adhere to paper, thus reducing osmotic stress [92], or application methods that deliver cell monolayers [93] that reduce self-shading without compromising cell viability. Another intriguing alternative is arrested coalescence using non-film forming particles (bimodal blends) mixed into the coating formulation to increase the porosity of coatings, which have been used with fungi and bacteria [77,94]. However, unless the particles are sufficiently transparent, bimodal blends may decrease light transmission. In addition, the non-film forming particles have to be non-toxic, inert (non-reactive to latex), ideally smaller sizes than the immobilised cells, and larger than latex particles [47]. However, this approach may increase the total capital cost of the biocomposites and may risk secondary pollution if non-biodegradable additives are used, e.g., microplastics.

There is an additional and as yet poorly understood factor, the biological response of the immobilised organism. The breadth of microalgae diversity that has been trialled for immobilisation is very small, generally reflecting model organisms and those considered as laboratory and industry 'workhorses'. Additionally, species that have been immobilised (e.g., Synechococcus elongatus, Chlorella vulgaris, Nannochloropsis oculata, Dunialella salina) tend to be among those considered as structurally robust and capable of withstanding the physical and chemical stressors associated with film formation and the consequent low-water existence. An acid test for ubiquitous tolerance for immobilisation would be to use more fragile species, notably among the dinoflagellates. Intuitively, we would expect low successes during immobilisation; however, once the cells are immobilised (assuming no damage) the structural support afforded by the latex may paradoxically extend cell longevity. Naturally, this is speculative, but it is an intriguing target for future work. Further, the capacity of microalgae to perform once immobilised is not universal. Indeed, we have documented variation in tolerance to immobilisation both across and within species [85,95]. The precise reasons for these variable responses are not known and will required detailed transcriptomic and metabolomic investigation.

\section{Bioinspiration from Lichen}

Many materials have been assessed for their suitability to support biofilm and biocoatings, although these have mostly been synthetic materials which may pose sustainability concerns. Natural, or even repurposed materials should improve the overall sustainability of biocomposites. Examples include recycled textiles which could function as 2D scaffolds [96]. However, it is important to consider rugosity when selecting textiles as the increased number of surface microstructures increases the hydrophobicity which may affect the formation of a uniform film [97]. Porosity ultimately impacts the homogenous formation of latex films, with more porous structures resulting in faster wicking leading to non-uniform film formation [98]. When utilising woven fabrics, the diameter and spacing of the weave affects the size of the inter-yarn pores which can increase the swelling capacity of the textile [99]. Additionally, highly porous fabrics such as cotton, have high levels of pore-collapse due to structural fragility leading to alterations in the number and distribution of pores [100]. Conversely, the pore size of non-woven fabrics is affected by fibre density, with less dense fibres having larger pores [101] which may lead to poorer microbial retention.

However, from biomedical applications it is well documented that the behaviour of cells grown on 2D surfaces differ to those in 3D matrices [102,103]. 3D scaffolds sustain improved cell proliferation and metabolic activity [104]. The ability to develop 3D structures supporting metabolically active cells permits the development of customisable culture systems [105]. However, before the nascent microalgae biocomposite field can afford serious consideration of 3D printed fabrication, we must advance the development of more affordable and easily accessible options. To progress from 2D to 3D biocomposite 
systems $[95,106]$, we have drawn inspiration from lichens—ancient composite organisms comprising fungi and photobionts (microalgae and/or cyanobacteria). More than $12 \%$ of Earth's land mass is lichen covered [107]. The photobionts live beneath a thin fungal layer (cortex) (Figure 5) which protects them from extreme environmental fluctuations (particularly desiccation). The fungus, which does not harm their photobionts but does influence their growth and cell turnover rates, benefits from the excess carbohydrates produced by the embedded photobionts. Most lichens can tolerate drought, extreme temperatures, can survive under nutrient scarcity and, where necessary can hibernate as part of a dormancy state [108]. These self-sustained microecosystems demonstrate that algae/cyanobacteria can live long and stable lives and operate under minimal quantities of water.

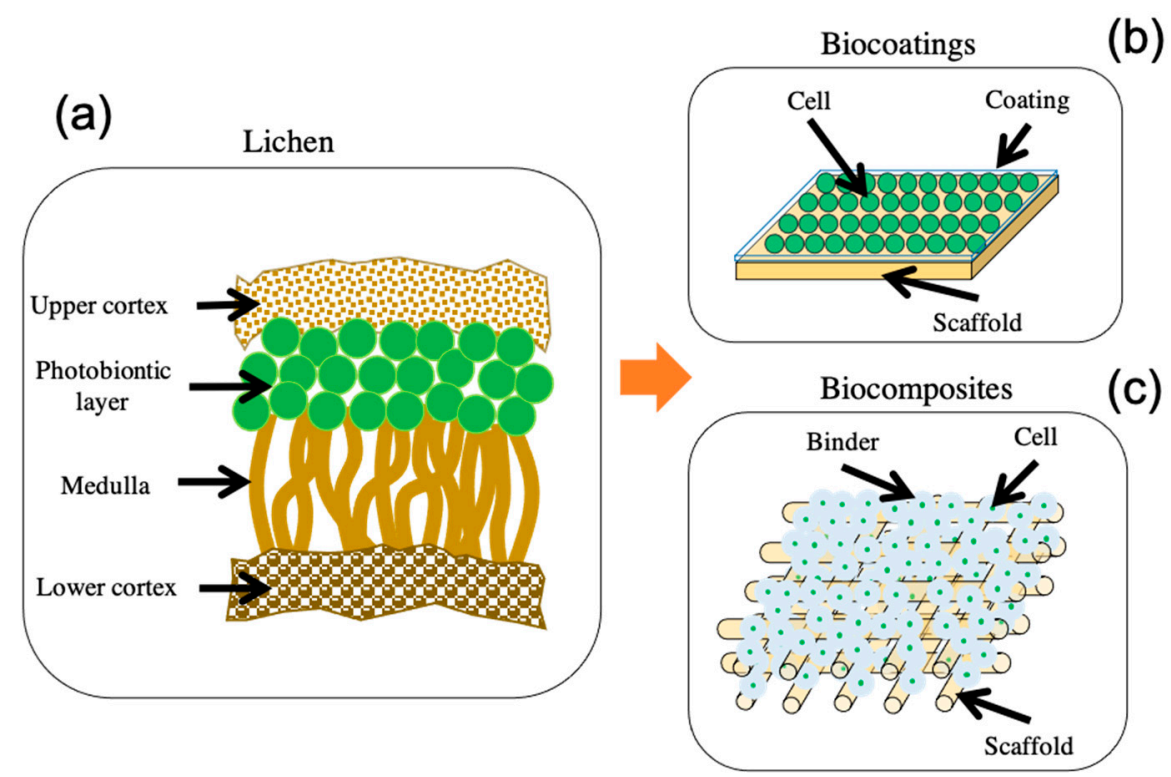

Figure 5. (a) Lichens are composite organisms comprising a fungus and a photobiont (microalgae and/or cyanobacteria). The fungal cortex secures and protects the photobiont which donates excess carbon (photosynthate) to its fungal host. The lichen structure provided the inspiration to evolve 2D biocomposites, wherein cells are deposited as a monolayer onto a flat scaffold such as paper (b) into 3D biocomposites, wherein cells are deposited on highly porous 3D scaffolds such as loofah sponge with the aid of non-toxic polymer binders, e.g., latex (c).

In this context, we have adopted the fibrous skeleton of Luffa-a member of the Cucurbitaceae family - commonly referred to as luffa or loofah sponge, as an exemplar sustainable, biodegradable 3D scaffold for algae biocomposites (Figure 6). The highly porous high surface area loofah structure (circa $950 \mathrm{~m}^{2} \mathrm{~m}^{-3}$ with $>80 \%$ void space) supports excellent gas exchange, facilitates reasonable light transmission and, with its hydrophilic nature is effective at retaining moisture within the structure $[85,109]$. We have demonstrated that loofah-based microalgae and cyanobacteria biocomposites can operate for many weeks as a means to biological $\mathrm{CO}_{2}$ capture without marked reduction in performance and with negligible maintenance requirements. In particular, the pairing of cyanobacteria with latex binders yielded a carbon capture potential to rival any existing algae-based system. Further, preliminary techno-economic analysis revealed that a scaled system would have a lower annualised $\mathrm{CO}_{2}$ avoidance cost than the closest algae comparator (a biofilm photobioreactor), with the added benefit of substantially reduced water and energy consumption [In-na et al. unpublished]. Subsequently, we have achieved substantial performance improvement by further optimising our biocomposite formulation (specifically that of the latex binder) [In-na, Sharp et al., unpublished]. Considering that the pre-optimised system was already rivalling the best performing (and long established) algae suspension and biofilm photobioreactors for $\mathrm{CO}_{2}$ capture, we see great scope 
for the development and roll-out of biocomposites across the gamut of microalgae and cyanobacteria biotechnology applications.

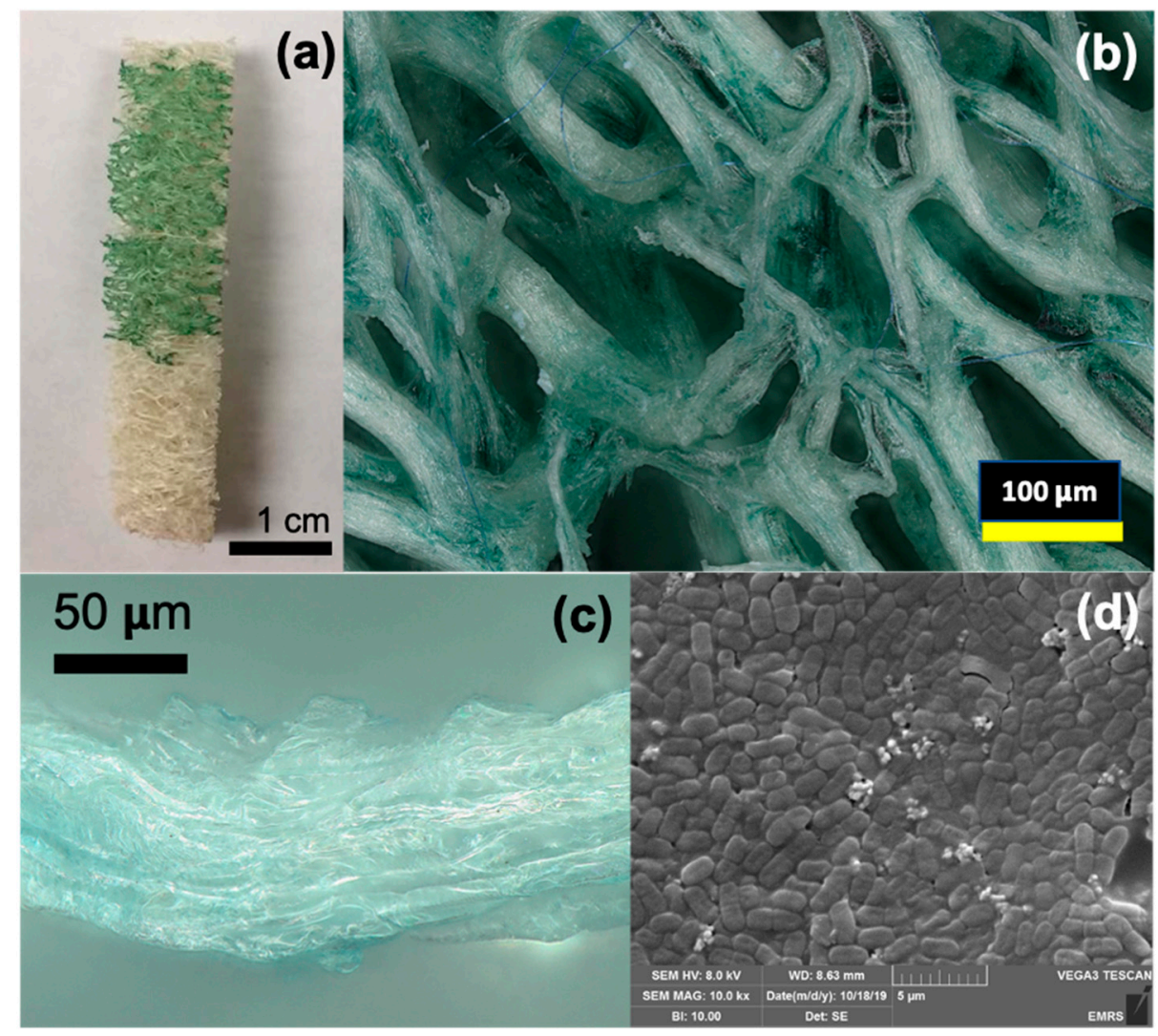

Figure 6. An example of a laboratory scale loofah-cyanobacteria biocomposite. (a) Prepared loofah strip coated with cyanobacteria (Synechococcus elongatus) enriched latex. (b) Higher magnification image of the coated loofah strands demonstrating the high surface area and high porosity of the scaffold. (c) Closer focus on an individual coated loofah strand. The latex coating is evidenced by the reflection of light. (d) SEM image of an S. elongatus biocoating demonstrating the close packed nature of the cells with the thin film latex biocoating.

\section{Biocomposites as Process Intensification}

Despite photobioreactors increasing the productivity and yield of suspension-based microalgae cultivation, scale-up inefficiencies continue to limit its economic feasibility. Process intensification (PI), conceptualised in the mid-1990's, is often used to reduce the physical size of operations while achieving set production objectives [110], and is applicable to mass microalgae culture [111]. Moving to immobilised minimal water cultivation would be a clear PI step.

Posten [112] defined photobioreactors in terms of four-phases: (1) solid phase-cells; (2) liquid phase-culture medium; (3) gas phase-air or $\mathrm{CO}_{2}$ enriched air; and (4) radiation phase-light. This classification remains appropriate for biocomposites, albeit on differing spatial (and perhaps even temporal) scales, and certainly with a shift in emphasis between the phases. Consider the solid phase. Posten's definition includes only the cells. This comparison holds true for biocomposites; albeit biocomposites present substantially greater cell densities than encountered in suspension culture. However, in a biocomposite the solid phase is dominant whereas the liquid phase dominates suspension cultivation and we must not only consider the cells but must also accommodate the influence of the scaffold and the binder. Figure 7 presents a scenario within a cyanobacteria biocomposite. If we consider water and nutrient transport, these molecules must traverse the liquid-solid interface separating the wetted film and the scaffold, to then encounter the solid-solid 
interface that defines the join between the scaffold and the binder. Clearly, were either scaffold or binder to be hydrophobic this would present a considerable barrier to water and solute transport. A key design consideration is therefore the surface properties of the biocomposite materials. A second solid-solid interface (the boundary between the binder and the cell wall) must then be crossed. The situation is more complex from a $\mathrm{CO}_{2}$ mass transfer perspective. $\mathrm{CO}_{2}$ has two main routes into the biocomposite; either transported as $\mathrm{HCO}_{3}{ }^{-}$along with water, requiring mass transfer from the gas phase into the liquid phase across a gas-liquid interface, and then following the path as described above, or by direct transfer from the gas phase across the binder where it may react with water to form $\mathrm{HCO}_{3}{ }^{-}$either within the binder or at the binder-cell interface. Both paths necessitate a degree of binder porosity. In both cases, these are predominantly physical interactions. There is added complexity once the inputs (water, nutrients, $\mathrm{CO}_{2}$, and $\mathrm{HCO}_{3}{ }^{-}$) encounter the cell, whereby further interfaces must be crossed, e.g., cell wall/plasma membrane, in addition to other intracellular barriers, e.g., carboxysome wall. However, in this respect biology delivers effective solutions such as transmembrane proteins (assuming that the organism remain viable) and the $\mathrm{CO}_{2}$ concentrating mechanism [113].

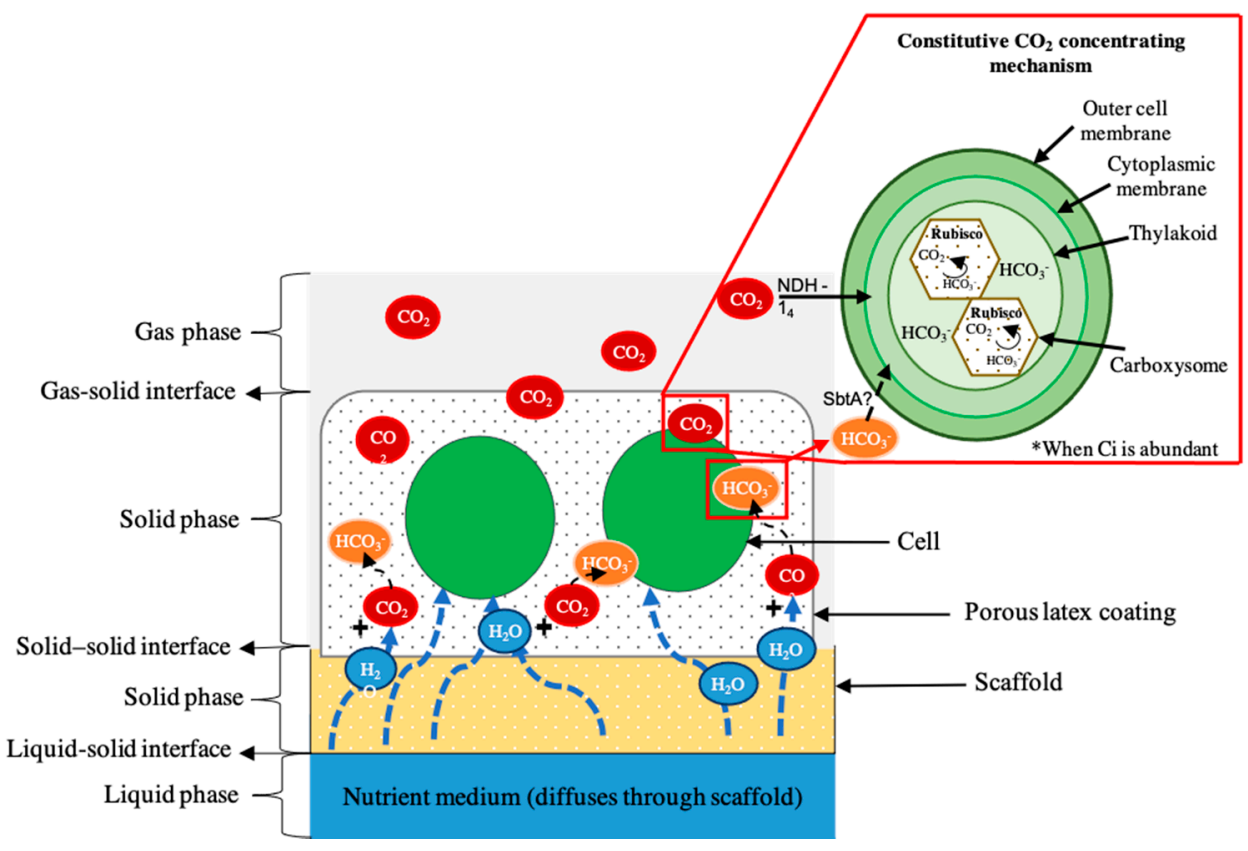

Figure 7. Illustrating the complexities of polymer entrapment to develop living and metabolically functional cyanobacteria biocomposites, with interactions with the $\mathrm{CO}_{2}$ concentrating mechanism to overcome photorespiration. The biocomposite design brief should specify the effective transport of water and nutrient solutes through capillary forces (wicking). The inclusion of hydrophilic scaffolds enables low moisture operation. The binder requires porosity without compromising integrity. Capacity for mass transfer of $\mathrm{CO}_{2}, \mathrm{O}_{2}$, water and nutrient solutes is essential to support the cell.

Light transmission is a further critical design consideration. Based on cell growth, photobioreactors may be considered as comprising three distinct light transfer zones. Firstly, as light passes through the photobioreactor wall the intensity can exceed the cell's ability to photosynthesise, having an inhibitory effect (photoinhibition). Light then reaches a maintenance zone in which cells can balance light and nutrient resources for sustained growth. Through self-shading, a reduced light transmission zone propagates towards the middle of the photobioreactor, reducing growth [114]. These issues can be ameliorated at the photobioreactor design stage; for example, access to light may be altered by changing the tube or plate diameter, by altering the construction materials or by regulating the quantity and quality of light, i.e., through artificial illumination. However, post-construction, the available options are more limited. Mixing is a mainstay 
of operational adjustment, facilitating homogenous light exposure and access to nutrients and $\mathrm{CO}_{2}$. When we consider these issues for biocomposites, at first glance it would appear that our capacity to fine tune the system is curtailed. For instance, biocomposites are default thin-film systems, thereby the capacity to regulate light transmission by changing culture vessel dimensions is limited. Equally, mixing is not an option. Intuitively, the cells within biocomposites (particularly those at the light facing surface) should be extremely vulnerable to photoinhibition and, given the high cell loadings that define biocomposites, there is a real risk that cells immobilised deeper within the biocomposite structure will be light limited, leaving little margin for error in designing the biocomposite equivalent of the photobioreactor maintenance zone. However, these potential issues can be designed out with comparative ease; indeed, it is possible to craft interesting opportunities out of apparent adversity.

Firstly, it is essential that any binder allows adequate transmission of photosynthetically active radiation (wavelength: $400-700 \mathrm{~nm}$ ), otherwise photosynthetic performance will be compromised. Latex, particularly when applied as a thin film, supports very good light transmission (Figure 8a). In situations where potentially damaging irradiances may be encountered it is possible to combat this either by altering the latex formulation (Figure $8 b$ ), or by the inclusion of reflective particles within the binder. Whereas there may be some loss of efficiency during low light periods, this may be an acceptable trade-off in particular situations to manage photoinhibition. In relation to self-shading driven light limitation, this is easily addressed by using very thin binder applications, potentially to the extent of creating cell monolayers. This avoids self-shading entirely and, paradoxically, favours the adoption of low light conditions. Such a configuration is particularly suited to indoor cultivation using artificial light and may translate into substantial energy savings.
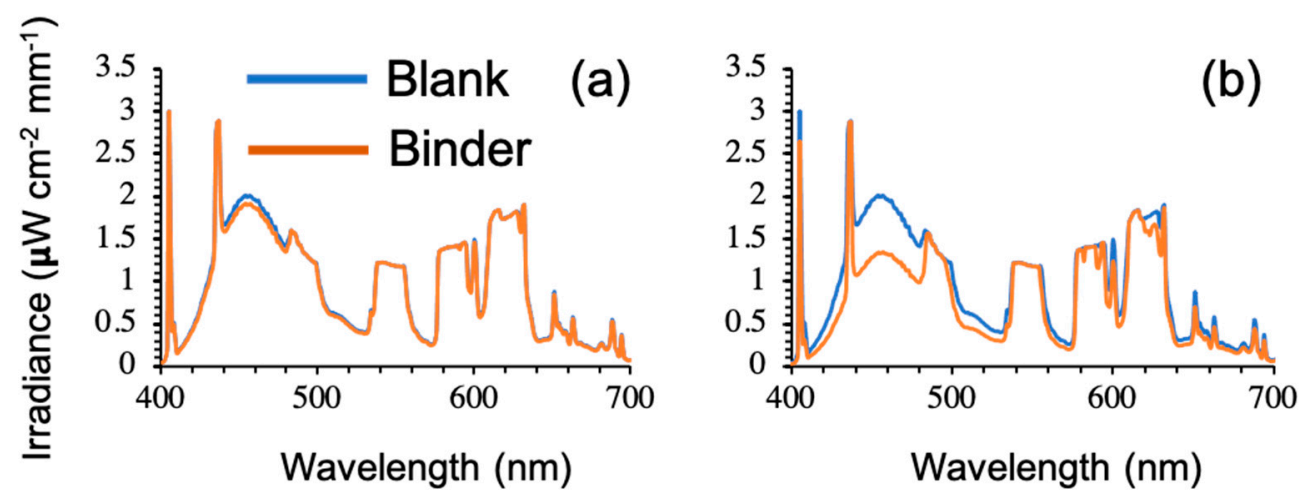

(c)

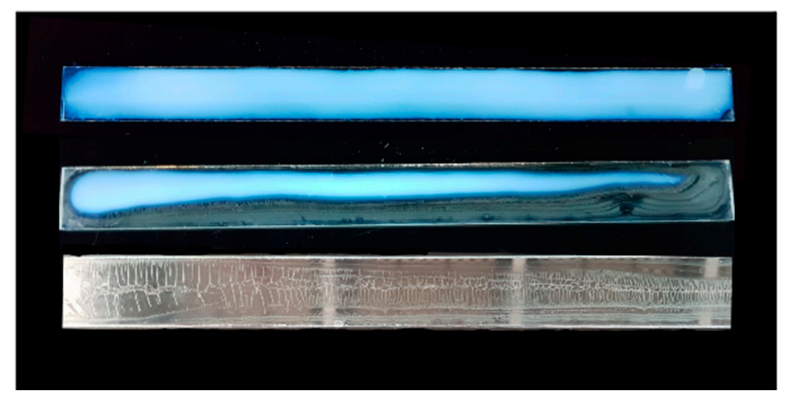

Figure 8. Latex based binders efficiently transmit photosynthetically active radiation to the cell (a), yet they may also be designed to filter certain wavelengths (b) such that photoinhibition may be managed in high light environments, (c) latex film formation on glass, with the upper image showing freshly applied wet latex (opaque), progressively becoming transparent as it dries (middle image), forming a fully transparent film (bottom image) [In-na, Sharp et al. unpublished]. 


\section{Immobilisation for Synthetic Biology}

There remains a significant gap in understanding the organisms' response to immobilisation. To progress the technology to commercial application, an increase in system productivity and reproducibility is required. Systems biology is providing greater insight into cellular and metabolic processes, and can be exploited to metabolically engineer microorganisms for enhanced performance [115]. Synthetic biology combines genetic engineering, systems biology, and computational modelling to design biological parts and systems, or redesign existing systems for greater productivity; tailoring the organism to work as effectively as possible, e.g., towards greater production of biochemicals, and by improving photosynthesis by enhancing light harvesting efficiency and $\mathrm{CO}_{2}$ fixation $[116,117]$. Wastewater treatment already relies, to some degree, on photosynthetic microbes for bioremediation; this could be intensified by enhancing the robustness of target synthetic microbes, simultaneously increasing $\mathrm{CO}_{2}$ capture [118]. Enhanced biosorption and biotransformation of nutrients or pollutants from wastewater will lead to higher treatment efficiency, but this is still in its infancy and limited to laboratory scale experiments. However, there are concerns about the use of synthetic microbes [119]. Accidental release could have significant, permanent effects on ecosystems. With large-scale cultivation, the escape of synthetic strains is inevitable, thus care should be taken to ensure the strain cannot establish outside of a controlled environment [120]. Containment within photobioreactors provides less risk as reactor design could feature mitigation measures such as sterilisation prior to release of wastewater, but open-ponds must have enhanced containment such as catchment areas, filters, or UV irradiation, and monitoring strategies when containing synthetic strains [121]. Physical controls can be extremely costly, so biocontainment is recommended by engineering strains to have specific requirements for survival that would not be naturally found.

The development of risk assessments is complex as the fitness of the synthetic strain, all native species of photosynthetic microbes, and all environmental perturbations must be accounted for if models for risk assessment are to have any real meaning [120]. The immobilisation of synthetic strains potentially alleviates some of the concerns about the accidental release by acting as another physical control. When immobilised onto loofah there was just $0.61 \%$ release of S. elongatus PCC 7942 after 72 h [85]. If both physical and genetic controls were applied, the risk of release to environment could be significantly reduced.

\section{Conclusions}

We have set out the rationale for immobilisation culture of microalgae as biocomposites within a process intensification framework, with a focus on latex-based systems, particularly for applications that demand prolonged environmental exposure (e.g., carbon capture), are vulnerable to biomass washout (e.g., wastewater bioremediation), or that require secure retention of the cells (e.g., synthetic biology). The choice of organism to immobilise should be driven by the end use of the process. In this article we have focused on applications for bioremediation (air and water), but the technology can be used for bioproducts synthesis, and we see great scope for roll-out as biosensors, particularly given the biocomposites' longevity and low levels of maintenance. Several improvements can be made to increase the performance of biocomposites, aside from targeted species selection. Further study on latex formulations can be used to optimise cell viability, gas mass transfer and photosynthetic performance. Parameters such as cell loading, total solids content of the binder, light intensity, light cycle, and nutrient concentration can greatly influence $\mathrm{CO}_{2}$ uptake but have not been adequately explored. For example, increasing cell loading can lead to higher competition for nutrients meaning nutrient concentration has to be increased. Design criteria for large-scale and longer-term use of biocomposites should consider the following key points: (1) the need for a biologically safe coating method that delivers a uniform coating throughout the scaffold; (2) the spatial arrangement of the biocomposite should not hinder light penetration to the cells that lie in the inner parts of the biocomposite; (3) the need for a nutrient delivery system that assists/augments the capillary action of 
loofah without compromising the structural integrity of the binder should be considered; and (4) the containment infrastructure for the biocomposites (if needed) should be cheap but robust enough to support long term operation as well as provide transparency for light penetration.

Author Contributions: All authors contributed to the conceptualisation of the article, writingoriginal draft preparation, G.S.C., P.I.-n., R.H., J.G.M.L.; writing-review and editing, E.S., M.P., M.W., M.U., J.P. All authors have read and agreed to the published version of the manuscript.

Funding: G.S.C. and R.H. received funding from EnviResearch, P.I. was supported by an International Postgraduate Scholarship (Reference number: 400345497) from the School of Engineering, Newcastle University; J.P. and E.S. were funded by the Engineering and Physical Sciences Research Council EPSRC (EP/R020957/1), M.P. was funded by Northumbrian Water Ltd., and A.S. was supported through Research England as part of the Hub for Biotechnology in the Built Environment.

Institutional Review Board Statement: Not applicable.

Informed Consent Statement: Not applicable.

Data Availability Statement: The data presented in this study are available on request from the corresponding author.

Conflicts of Interest: The authors declare no conflict of interest. The funders had no role in the writing of the manuscript, or in the decision to publish.

\section{References}

1. Chisti, Y. Biodiesel from microalgae. Biotechnol. Adv. 2007, 25, 294-306. [CrossRef]

2. Supriyanto Noguchi, R.; Ahamed, T.; Rani, D.S.; Sakurai, K.; Nasution, M.A.; Wibawa, D.S.; Demura, M.; Watanabe, M.M. Artificial neural networks model for estimating growth of polyculture microalgae in an open raceway pond. Biosyst. Eng. 2019, 177, 122-129. [CrossRef]

3. Chandra, R.; Amit Ghosh, U.K. Effects of various abiotic factors on biomass growth and lipid yield of Chlorella minutissima for sustainable biodiesel production. Environ. Sci. Pollut. Res. 2019, 26, 3848-3861. [CrossRef] [PubMed]

4. Flynn, K.J.; Greenwell, H.C.; Lovitt, R.W.; Shields, R.J. Selection for fitness at the individual or population levels: Modelling effects of genetic modifications in microalgae on productivity and environmental safety. J. Theor. Biol. 2010, 263, 269-280. [CrossRef]

5. Hidasi, N.; Belay, A. Diurnal variation of various culture and biochemical parameters of Arthrospira platensis in large-scale outdoor raceway ponds. Algal Res. 2018, 29, 121-129. [CrossRef]

6. Sutherland, D.L.; Howard-Williams, C.; Turnbull, M.H.; Broady, P.A.; Craggs, R.J. Seasonal variation in light utilisation, biomass production and nutrient removal by wastewater microalgae in a full-scale high-rate algal pond. J. Appl. Phycol. 2014, 26, 1317-1329. [CrossRef]

7. Unnithan, V.V.; Unc, A.; Smith, G.B. Mini-review: A priori considerations for bacteria-algae interactions in algal biofuel systems receiving municipal wastewaters. Algal Res. 2014, 4, 35-40. [CrossRef]

8. Ugwu, C.; Aoyagi, H.; Uchiyama, H. Photobioreactors for mass cultivation of algae. Bioresour. Technol. 2008, 99, 4021-4028. [CrossRef] [PubMed]

9. Delrue, F.; Setier, P.-A.; Sahut, C.; Cournac, L.; Roubaud, A.; Peltier, G.; Froment, A.-K. An economic, sustainability, and energetic model of biodiesel production from microalgae. Bioresour. Technol. 2012, 111, 191-200. [CrossRef] [PubMed]

10. Richardson, J.W.; Johnson, M.D.; Outlaw, J.L. Economic comparison of open pond raceways to photo bio-reactors for profitable production of algae for transportation fuels in the Southwest. Algal Res. 2012, 1,93-100. [CrossRef]

11. de Godos, I.; Mendoza, J.L.; Acien, F.G.; Molina, E.; Banks, C.J.; Heaven, S.; Rogalla, F. Evaluation of carbon dioxide mass transfer in raceway reactors for microalgae culture using flue gases. Bioresour. Technol. 2014, 153, 307-314. [CrossRef]

12. Wang, J.; Liu, W.; Liu, T. Biofilm based attached cultivation technology for microalgal biorefineries-A review. Bioresour. Technol. 2017, 244 Pt 2, 1245-1253. [CrossRef]

13. Mantzorou, A.; Ververidis, F. Microalgal biofilms: A further step over current microalgal cultivation techniques. Sci. Total Environ. 2019, 651 Pt 2, 3187-3201. [CrossRef]

14. Shen, Y.; Chen, C.; Chen, W.; Xu, X. Attached culture of Nannochloropsis oculata for lipid production. Bioprocess. Biosyst. Eng. 2014, 37, 1743-1748. [CrossRef] [PubMed]

15. Liu, T.; Wang, J.; Hu, Q.; Cheng, P.; Ji, B.; Liu, J.; Chen, Y.; Zhang, W.; Chen, X.; Chen, L.; et al. Attached cultivation technology of microalgae for efficient biomass feedstock production. Bioresour. Technol. 2013, 127, 216-222. [CrossRef]

16. Rincon, S.M.; Romero, H.M.; Aframehr, W.M.; Beyenal, H. Biomass production in Chlorella vulgaris biofilm cultivated under mixotrophic growth conditions. Algal Res. 2017, 26, 153-160. [CrossRef] 
17. Zhang, Q.; Li, X.; Guo, D.; Ye, T.; Xiong, M.; Zhu, L.; Liu, C.; Jin, S.; Hu, Z. Operation of a vertical algal biofilm enhanced raceway pond for nutrient removal and microalgae-based byproducts production under different wastewater loadings. Bioresour. Technol. 2018, 253, 323-332. [CrossRef] [PubMed]

18. Xu, X.-Q.; Wang, J.-H.; Zhang, T.-Y.; Dao, G.-H.; Wu, G.-X.; Hu, H.-Y. Attached microalgae cultivation and nutrients removal in a novel capillary-driven photo-biofilm reactor. Algal Res. 2017, 27, 198-205. [CrossRef]

19. Martín-Girela, I.; Curt, M.D.; Fernández, J. Flashing light effects on $\mathrm{CO}_{2}$ absorption by microalgae grown on a biofilm photobioreactor. Algal Res. 2017, 25, 421-430. [CrossRef]

20. Martins, S.C.S.; Martins, C.M.; Fiúza, L.M.C.G.; Santaella, S.T. Immobilization of microbial cells: A promising tool for treatment of toxic pollutants in industrial wastewater. Afr. J. Biotechnol. 2013, 12, 4412-4418.

21. Hamano, H.; Nakamura, S.; Hayakawa, J.; Miyashita, H.; Harayama, S. Biofilm-based photobioreactor absorbing water and nutrients by capillary action. Bioresour. Technol. 2017, 223, 307-311. [CrossRef] [PubMed]

22. Schultze, L.K.P.; Simon, M.-V.; Li, T.; Langenbach, D.; Podola, B.; Melkonian, M. High light and carbon dioxide optimize surface productivity in a twin-layer biofilm photobioreactor. Algal Res. 2015, 8, 37-44. [CrossRef]

23. Travieso, L.; Benitez, F.; Weiland, P.; Sanchez, E.; Dupeyron, R.; Dominguez, A.R. Experiments on immobilization of microalgae for nutrient removal in wastewater treatments. Bioresour. Technol. 1996, 55, 181-186. [CrossRef]

24. Thepenier, C.; Gudin, C. Immobilization of Porphyridium cruentum in polyurethane foams for the production of polysaccharide. Biomass 1985, 7, 225-240. [CrossRef]

25. Lee, S.H.; Oh, H.M.; Jo, B.H.; Lee, S.A.; Shin, S.Y.; Kim, H.S.; Lee, S.H.; Ahn, C.Y. Higher biomass productivity of microalgae in an attached growth system, using wastewater. J. Microbiol. Biotechnol. 2014, 24, 1566-1573. [CrossRef] [PubMed]

26. Ozkan, A.; Kinney, K.; Katz, L.; Berberoglu, H. Reduction of water and energy requirement of algae cultivation using an algae biofilm photobioreactor. Bioresour. Technol. 2012, 114, 542-548. [CrossRef]

27. Hoh, D.; Watson, S.; Kan, E. Algal biofilm reactors for integrated wastewater treatment and biofuel production: A review. Chem. Eng. J. 2016, 287, 466-473. [CrossRef]

28. Gross, M.; Henry, W.; Michael, C.; Wen, Z. Development of a rotating algal biofilm growth system for attached microalgae growth with in situ biomass harvest. Bioresour. Technol. 2013, 150, 195-201. [CrossRef]

29. Christenson, L.B.; Sims, R.C. Rotating algal biofilm reactor and spool harvester for wastewater treatment with biofuels by-products. Biotechnol. Bioeng. 2012, 109, 1674-1684. [CrossRef]

30. Akhtar, N.; Iqbal, J.; Iqbal, M. Removal and recovery of nickel(II) from aqueous solution by loofa sponge-immobilized biomass of Chlorella sorokiniana: Characterization studies. J. Hazard. 2004, 108, 85-94. [CrossRef] [PubMed]

31. Akhtar, N.; Saeed, A.; Iqbal, M. Chlorella sorokiniana immobilized on the biomatrix of vegetable sponge of Luffa cylindrica: A new system to remove cadmium from contaminated aqueous medium. Bioresour. Technol. 2003, 88, 163-165. [CrossRef]

32. Xiao, R.; Zheng, Y. Overview of microalgal extracellular polymeric substances (EPS) and their applications. Biotechnol. Adv. 2016, 34, 1225-1244. [CrossRef] [PubMed]

33. Berner, F.; Heimann, K.; Sheehan, M. Microalgal biofilms for biomass production. J. Appl. Phycol. 2014, 27, 1793-1804. [CrossRef]

34. Gross, M.; Wen, Z. Yearlong evaluation of performance and durability of a pilot-scale Revolving Algal Biofilm (RAB) cultivation system. Bioresour. Technol. 2014, 171, 50-58. [CrossRef] [PubMed]

35. Blanken, W.; Janssen, M.; Cuaresma, M.; Libor, Z.; Bhaiji, T.; Wijffels, R.H. Biofilm growth of Chlorella sorokiniana in a rotating biological contactor based photobioreactor. Biotechnol. Bioeng. 2014, 111, 2436-2445. [CrossRef] [PubMed]

36. Johnson, M.B.; Wen, Z. Development of an attached microalgal growth system for biofuel production. Appl. Microbiol. Biotechnol. 2010, 85, 525-534. [CrossRef]

37. Ouspensky, P.D. The Fourth Way: A Record of Talks and Answers to Questions Based on the Teaching of G.I. Gurdjieff; Routledge \& Kegan Paul: London, UK, 1957.

38. Pinck, S.; Etienne, M.; Dossot, M.; Jorand, F.P.A. A rapid and simple protocol to prepare a living biocomposite that mimics electroactive biofilms. Bioelectrochemistry 2017, 118, 131-138. [CrossRef]

39. de-Bashan, L.E.; Bashan, Y. Immobilized microalgae for removing pollutants: Review of practical aspects. Bioresour. Technol. 2010, 101, 1611-1627. [CrossRef] [PubMed]

40. Mallick, N. Biotechnological potential of immobilized algae for wastewater N, P and metal removal: A review. BioMetals 2002. [CrossRef] [PubMed]

41. Berger, R.G. Biotechnology of flavours-The next generation. Biotechnol. Lett. 2009, 31, 1651. [CrossRef] [PubMed]

42. Carballeira, J.D.; Quezada, M.A.; Hoyos, P.; Simeó, Y.; Hernaiz, M.J.; Alcantara, A.R.; Sinisterra, J.V. Microbial cells as catalysts for stereoselective red-ox reactions. Biotechnol. Adv. 2009, 27, 686-714. [CrossRef] [PubMed]

43. Demain, A.L. Biosolutions to the energy problem. J. Ind. Microbiol. Biotechnol. 2009, 36, 319-332. [CrossRef] [PubMed]

44. Rao, N.N.; Lütz, S.; Würges, K.; Minör, D. Continuous biocatalytic processes. Org. Process. Res. Dev. 2009, 13, 607-616. [CrossRef]

45. End, N.; Schöning, K.-U. Immobilized biocatalysts in industrial research and production. In Immobilized Catalysts: Solid Phases, Immobilization and Applications; Kirschning, A., Ed.; Springer: Berlin/Heidelberg, Germany, 2004; pp. $273-317$.

46. Flickinger, M.C.; Fidaleo, M.; Gosse, J.; Polzin, K.; Charaniya, S.; Solheid, C.; Lyngberg, O.K.; Laudon, M.; Ge, H.; Schottel, J.L.; et al. Engineering Nanoporous Bioactive Smart Coatings Containing Microorganisms: Fundamentals and Emerging Applications; ACS Symposium Series; American Chemical Society: Washington, DC, USA, 2009. 
47. Flickinger, M.C.; Schottel, J.L.; Bond, D.R.; Aksan, A.; Scriven, L.E. Painting and printing living bacteria: Engineering nanoporous biocatalytic coatings to preserve microbial viability and intensify reactivity. Biotechnol. Prog. 2007, 23, 2-17. [CrossRef]

48. Cohan, Y. Biofiltration-The treatment of fluids by microorganisms immobilized into the filter bedding material: A review. Bioresour. Technol. 2001, 77, 257-274. [CrossRef]

49. Moreno-Garrido, I. Microalgae immobilization: Current techniques and uses. Bioresour. Technol. 2008, 99, 3949-3964. [CrossRef]

50. Magdeldin, S.; Moser, A. Affinity Chromatography: Principles and Applications; InTech: Rijeka, Croatia, 2012.

51. Chandramohan, D.; Marimuthu, K. A review on natural fibers. Int. J. Res. Rev. Appl. Sci. 2011, 8, $194-206$.

52. Gurunathan, T.; Mohanty, S.; Nayak, S.K. A review of the recent developments in biocomposites based on natural fibres and their application perspectives. Compos. Part A Appl. Sci. Manuf. 2015, 77, 1-25. [CrossRef]

53. Holzmeister, I.; Schamel, M.; Groll, J.; Gbureck, U.; Vorndran, E. Artificial inorganic biohybrids: The functional combination of microorganisms and cells with inorganic materials. Acta Biomater. 2018. [CrossRef]

54. Perullini, M.; Rivero, M.M.; Jobbágy, M.; Mentaberry, A.; Bilmes, S.A. Plant cell proliferation inside an inorganic host. J. Biotechnol. 2007, 127, 542-548. [CrossRef] [PubMed]

55. Mallick, N.; Rai, L.C. Removal and assessment of toxicity of $\mathrm{Cu}$ and Fe to Anabaena doliolum and Chloreila vulgaris using free and immobilized cells. World J. Microbiol. Biotechnol. 1992, 8, 110-114.

56. Yashveer, S. Photosynthetic activity, and lipid and hydracarbon production by alginate-immobilized cells of Botryococcus in relation to growth phase. J. Microbiol. Biotechnol. 2003, 13, 687-691.

57. Pannier, A.; Soltmann, U.; Soltmann, B.; Altenburger, R.; Schmitt-Jansen, M. Alginate/silica hybrid materials for immobilization of green microalgae Chlorella vulgaris for cell-based sensor arrays. J. Mater. Chem. B 2014, 2, 7896-7909. [CrossRef] [PubMed]

58. Desmet, J.; Meunier, C.F.; Danloy, E.P.; Duprez, M.-E.; Hantson, A.-L.; Thomas, D.; Cambier, P.; Rooke, J.C.; Su, B.-L. Green and sustainable production of high value compounds via a microalgae encapsulation technology that relies on $\mathrm{CO}_{2}$ as a principle reactant. J. Mater. Chem. A 2014, 2, 20560-20569. [CrossRef]

59. Lode, A.; Krujatz, F.; Brüggemeier, S.; Quade, M.; Schütz, K.; Knaack, S.; Weber, J.; Bley, T.; Gelinsky, M. Green bioprinting: Fabrication of photosynthetic algae-laden hydrogel scaffolds for biotechnological and medical applications. Eng. Life Sci. 2015, 15, 177-183. [CrossRef]

60. Malik, S.; Hagopian, J.; Mohite, S.; Lintong, C.; Stoffels, L.; Giannakopoulos, S.; Beckett, R.; Leung, C.; Ruiz, J.; Cruz, M.; et al. Robotic extrusion of algae-laden hydrogels for large-scale applications. Glob. Chall. 2020, 4, 1900064. [CrossRef] [PubMed]

61. Eroglu, E.; Smith, S.M.; Raston, C.L. Application of various immobilization techniques for algal bioprocesses. In Biomass and Biofuels from Microalgae. Biofuel and Biorefinery Technologies; Moheimani, N., McHenry, M., de Boer, K., Bahri, P., Eds.; Springer: Berlin/Heidelberg, Germany, 2015; Volume 2, pp. 19-44.

62. Kuu, W.Y.; Polack, J.A. Improving immobilized biocatalysts by gel phase polymerization. Biotechnol. Bioeng. 1983, 25, 1995-2006. [CrossRef] [PubMed]

63. Faafeng, B.A.; van Donk, E.; Källqvist, S.T. In situ measurement of algal growth potential in aquatic ecosystems by immobilized algae. Appl. Phycol. 1994, 6, 301-308. [CrossRef]

64. Serp, D.; Cantana, E.; Heinzen, C.; Stockar, U.V.; Marison, I.W. Characterization of an encapsulation device for the production of monodisperse alginate beads for cell immobilization. Biotechnol. Bioeng. 2000, 70, 41-53. [CrossRef]

65. Lau, P.S.; Tam, N.F.Y.; Wong, Y.S. Effect of carrageenan immobilization on the physiological activities of Chlorella vulgaris. Bioresour Technol. 1998, 63, 115-121. [CrossRef]

66. Chevalier, P.; de la Noüe, J. Wastewater nutrient removal with microalgae immobilized in carrageenan. Enzym. Microb. Technol. 1985, 7, 621-624. [CrossRef]

67. McHugh, D.J. A guide to the seaweed industry. In FAO Fisheries Technical Paper; FAO: Rome, Italy, $2003 ;$ p. 441.

68. Tavassoli-Kafrani, E.; Shekarchizadeh, H.; Masoudpour-Behabadi, M. Development of edible films and coatings from alginates and carrageenans. Carbohydr. Polym. 2016, 137, 360-374. [CrossRef] [PubMed]

69. Aguilar-May, B.; del Pilar Sánchez-Saavedra, M.; Lizardi, J.; Voltolina, D. Growth of Synechococcus sp. immobilized in chitosan with different times of contact with NaOH. J. Appl. Phycol. 2007, 19, 181-183. [CrossRef]

70. Mallick, N.; Rai, L.C. Removal of inorganic ions from wastewaters by immobilized microalgae. World J. Microbiol. Biotechnol. 1994, 10, 439-443. [CrossRef]

71. Ekins-Coward, T.; Boodhoo, K.V.K.; Velasquez-Orta, S.; Caldwell, G.; Wallace, A.; Barton, R.; Flickinger, M.C. A microalgae biocomposite-integrated spinning disk bioreactor (SDBR): Toward a scalable engineering approach for bioprocess intensification in light-driven $\mathrm{CO}_{2}$ absorption applications. Ind. Eng. Chem. Res. 2019, 58, 5936-5949. [CrossRef]

72. Vorlop, K.D.; Klein, J. Entrapment of microbial cells in chitosan. In Methods in Enzymology; Academic Press: Cambridge, MA, USA, 1987; Volume 135, pp. 259-268.

73. Castro-Ceseña, A.B.; del Pilar Sánchez-Saavedra, M.; Ruíz-Güereca, D.A. Optimization of entrapment efficiency and evaluation of nutrient removal (N and P) of Synechococcus elongatus in novel core-shell capsules. J. Appl. Phycol. 2016, 28, 2343-2351. [CrossRef]

74. Cortez, S.; Nicolau, A.; Flickinger, M.C.; Mota, M. Biocoatings: A new challenge for environmental biotechnology. Biochem. Eng. J. 2017, 121, 25-37. [CrossRef]

75. Guy, A. The science and art of paint formulation. Chem. Phys. Coat. 2004, 317-346. [CrossRef]

76. Lyngberg, O.K.; Stemke, D.J.; Schottel, J.L.; Flickinger, M.C. A single-use luciferase-based mercury biosensor using Escherichia coli HB101 immobilized in a latex copolymer film. J. Ind. Microbiol. Biotechnol. 1999, 23, 668-676. [CrossRef] [PubMed] 
77. Jenkins, J.S.; Flickinger, M.C.; Velev, O.D. Deposition of composite coatings from particle-particle and particle-yeast blends by convective-sedimentation assembly. J. Colloid Interface Sci. 2012, 380, 192-200. [CrossRef] [PubMed]

78. Price, K.; Wu, W.; McCormick, A.V.; Francis, L.F. Measurements of stress development in latex coatings. In Protective Coatings: Film Formation and Properties; Wen, M., Dušek, K., Eds.; Springer International Publishing: Cham, Switzerland, 2017; pp. 225-240.

79. Bunning, T.J.; Lawton, C.W.; Klei, H.E.; Sundstrom, D.W. Physical property improvements of a pellicular biocatalyst. Bioprocess. Eng. 1991, 7, 71-75. [CrossRef]

80. Flickinger, M.C.; Bernal, O.I.; Schulte, M.J.; Broglie, J.J.; Duran, C.J.; Wallace, A.; Mooney, C.B.; Velev, O.D. Biocoatings: Challenges to expanding the functionality of waterborne latex coatings by incorporating concentrated living microorganisms. J. Coat. Technol. Res. 2017, 14, 791-808. [CrossRef]

81. Martens, N.; Hall, E.A.H. Immobilisation of photosynthetic cells based on film-forming emulsion polymers. Anal. Chim. Acta 1994, 292, 49-63. [CrossRef]

82. Bernal, O.I.; Pawlak, J.J.; Flickinger Michael, C. Microbial paper: Cellulose fiber-based photo-absorber producing hydrogen gas from acetate using dry-stabilized Rhodopseudomonas palustris. BioResources 2017, 12, 4013-4030. [CrossRef]

83. Bernal, O.I.; Mooney, C.B.; Flickinger, M.C. Specific photosynthetic rate enhancement by cyanobacteria coated onto paper enables engineering of highly reactive cellular biocomposite "leaves". Biotechnol. Bioeng. 2014, 111, 1993-2008. [CrossRef] [PubMed]

84. Lyngberg, O.K.; Ng, C.P.; Thiagarajan, V.; Scriven, L.E.; Flickinger, M.C. Engineering the microstructure and permeability of thin multilayer latex biocatalytic coatings containing E. coli. Biotechnol. Prog. 2001, 17, 1169-1179. [CrossRef]

85. In-na, P.; Umar, A.A.; Wallace, A.D.; Flickinger, M.C.; Caldwell, G.S.; Lee, J.G.M. Loofah-based microalgae and cyanobacteria biocomposites for intensifying carbon dioxide capture. J. Co2 Util. 2020, 42, 101348. [CrossRef]

86. Wicks, J.Z.W.; Jones, F.; Peppas, S. Organic coatings: Science and technology volume 1: Film formation, components and appearance. Dry. Technol. 1993, 11, 1477. [CrossRef]

87. Reyes, Y.; Campos-Terán, J.; Vázquez, F.; Duda, Y. Properties of films obtained from aqueous polymer dispersions: Study of drying rate and particle polydispersity effects. Model. Simul. Mater. Sci. Eng. 2007, 15, 355. [CrossRef]

88. Chen, X.; Fischer, S.; Men, Y. Temperature and relative humidity dependency of film formation of polymeric latex dispersions. Langmuir 2011, 27, 12807-12814. [CrossRef]

89. Limousin, E.; Ballard, N.; Asua, J.M. The influence of particle morphology on the structure and mechanical properties of films cast from hybrid latexes. Prog. Org. Coat. 2019, 129, 69-76. [CrossRef]

90. Mesic, B.; Cairns, M.; Järnstrom, L.; Joo Le Guen, M.; Parr, R. Film formation and barrier performance of latex based coating: Impact of drying temperature in a flexographic process. Prog. Org. Coat. 2019, 129, 43-51. [CrossRef]

91. Schulte, M.J.; Wiltgen, J.; Ritter, J.; Mooney, C.B.; Flickinger, M.C. A high gas fraction, reduced power, syngas bioprocessing method demonstrated with a Clostridium ljungdahlii OTA1 paper biocomposite. Biotechnol. Bioeng. 2016, 113, 1913-1923. [CrossRef]

92. Gosse, J.L.; Chinn, M.S.; Grunden, A.M.; Bernal, O.I.; Jenkins, J.S.; Yeager, C.; Kosourov, S.; Seibert, M.; Flickinger, M.C. A versatile method for preparation of hydrated microbial-latex biocatalytic coatings for gas absorption and gas evolution. J. Ind. Microbiol. Biotechnol. 2012, 39, 1269-1278. [CrossRef] [PubMed]

93. Bernal, O.I.; Bharti, B.; Flickinger, M.C.; Velev, O.D. Fabrication of photoreactive biocomposite coatings via electric field-assisted assembly of cyanobacteria. Langmuir 2017, 33, 5304-5313. [CrossRef]

94. Chen, Y.; Krings, S.; Booth, J.R.; Bon, S.A.F.; Hingley-Wilson, S.; Keddie, J.L. Introducing porosity in colloidal biocoatings to increase bacterial viability. Biomacromolecules 2020. [CrossRef] [PubMed]

95. Hart, R.; In-na, P.; Kapralov, M.V.; Lee, J.G.M.; Caldwell, G.S. Textile-based cyanobacteria biocomposites for potential environmental remediation applications. J. Appl. Phycol. 2021. [CrossRef]

96. Koszewska, M. Circular economy-Challenges for the textile and clothing industry. Autex Res. J. 2018, 18, 337-347. [CrossRef]

97. Melki, S.; Biguenet, F.; Dupuis, D. Hydrophobic properties of textile materials: Robustness of hydrophobicity. J. Text. Inst. 2019, 110, 1221-1228. [CrossRef]

98. Khosravi, A.; King, J.A.; Jamieson, H.L.; Lind, M.L. Latex barrier thin film formation on porous substrates. Langmuir 2014, 30, 13994-14003. [CrossRef] [PubMed]

99. Sarkar, M.K.; He, F.A.; Fan, J.T. Moisture-responsive fabrics based on the hygro deformation of yarns. Text. Res. J. 2009, 80, 1172-1179. [CrossRef]

100. Dhiman, R.; Chattopadhyay, R. Absorbency of synthetic urine by cotton nonwoven fabric. J. Text. Inst. 2020, 1-8. [CrossRef]

101. Alassod, A.; Xu, G. Comparative study of polypropylene nonwoven on structure and wetting characteristics. J. Text. Inst. 2020, 1-8. [CrossRef]

102. Ozbolat, I.T.; Peng, W.; Ozbolat, V. Application areas of 3D bioprinting. Drug Discov. Today 2016, 21, 1257-1271. [CrossRef] [PubMed]

103. Jensen, C.; Teng, Y. Is it time to start transitioning from 2D to 3D cell culture? Front. Mol. Biosci. 2020, 7, 33. [CrossRef] [PubMed]

104. Zhao, S.; Guo, C.; Kumarasena, A.; Omenetto, F.G.; Kaplan, D.L. 3D printing of functional microalgal silk structures for environmental applications. ACS Biomater. Sci. Eng. 2019, 5, 4808-4816. [CrossRef] [PubMed]

105. Mehrotra, S.; Kumar, S.; Srivastava, V.; Mishra, T.; Mishra, B.N. 3D bioprinting in plant science: An interdisciplinary approach. Trends Plant Sci. 2020, 25, 9-13. [CrossRef] [PubMed]

106. Inna, P.; Caldwell, G.S.; Lee, J.G.M. Living textile biocomposites deliver enhanced carbon dioxide capture. J. Ind. Text. 2021. In press. 
107. Watkinson, S.C. The Fungi; Elsevier Science \& Technology: Amsterdam, The Netherlands, 2015.

108. Honegger, R. Lichen-forming fungi and their photobionts. In The Mycota; Springer: Berlin/Heidelberg, Germany, 2009; pp. 307-333.

109. Chen, Y.; Su, N.; Zhang, K.; Zhu, S.; Zhu, Z.; Qin, W.; Yang, Y.; Shi, Y.; Fan, S.; Wang, Z.; et al. Effect of fiber surface treatment on structure, moisture absorption and mechanical properties of luffa sponge fiber bundles. Ind. Crops Prod. 2018, 123, 341-352. [CrossRef]

110. Dautzenberg, F.; Mukherjee, M. Process intensification using multifunctional reactors. Chem. Eng. Sci. 2001, 56, $251-267$. [CrossRef]

111. Joshi, S.; Gogate, P. Process intensification of biofuel production from microalgae. In Energy from Microalgae; Springer: Berlin/Heidelberg, Germany, 2018; pp. 59-87.

112. Posten, C. Design principles of photo-bioreactors for cultivation of microalgae. Eng. Life Sci. 2009, 9, 165-177. [CrossRef]

113. Kupriyanova, E.V.; Sinetova, M.A.; Cho, S.M.; Park, Y.I.; Los, D.A.; Pronina, N.A. $\mathrm{CO}_{2}$-concentrating mechanism in cyanobacterial photosynthesis: Organization, physiological role, and evolutionary origin. Photosynth. Res. 2013, 117, 133-146. [CrossRef]

114. Bitog, J.P.; Lee, I.-B.; Lee, C.-G.; Kim, K.-S.; Hwang, H.-S.; Hong, S.-W.; Seo, I.-H.; Kwon, K.-S.; Mostafa, E. Application of computational fluid dynamics for modeling and designing photobioreactors for microalgae production: A review. Comput. Electron. Agric. 2011, 76, 131-147. [CrossRef]

115. Dangi, A.K.; Sharma, B.; Hill, R.T.; Shukla, P. Bioremediation through microbes: Systems biology and metabolic engineering approach. Crit. Rev. Biotechnol. 2019, 39, 79-98. [CrossRef] [PubMed]

116. Huang, H.-H.; Camsund, D.; Lindblad, P.; Heidorn, T. Design and characterization of molecular tools for a synthetic biology approach towards developing cyanobacterial biotechnology. Nucleic Acids Res. 2010, 38, 2577-2593. [CrossRef] [PubMed]

117. Sharma, B.; Dangi, A.K.; Shukla, P. Contemporary enzyme based technologies for bioremediation: A review. J. Environ. Manag. 2018, 210, 10-22. [CrossRef] [PubMed]

118. Gerotto, C.; Norici, A.; Giordano, M. Toward enhanced fixation of $\mathrm{CO}_{2}$ in aquatic biomass: Focus on microalgae. Front. Energy Res. 2020, 8, 213. [CrossRef]

119. Dana, G.V.; Kuiken, T.; Rejeski, D.; Snow, A.A. Four steps to avoid a synthetic-biology disaster. Nature 2012, 483, 29. [CrossRef]

120. Gressel, J.; van der Vlugt, C.J.; Bergmans, H.E. Cultivated microalgae spills: Hard to predict/easier to mitigate risks. Trends Biotechnol. 2014, 32, 65-69. [CrossRef] [PubMed]

121. Glass, D.J. Government regulation of the uses of genetically modified algae and other microorganisms in biofuel and bio-based chemical production. In Algal Biorefineries; Springer: Berlin/Heidelberg, Germany, 2015; pp. $23-60$. 